\title{
David Oliver: Keeping older doctors in the job
}

\author{
David Oliver consultant in geriatrics and acute general medicine
}

Berkshire

I'm 51. I started working as an NHS doctor at 23 and got my first consultant job at 32. My father, Fred, was one of the NHS's first consultant general adult psychiatrists to subspecialise in old age psychiatry. His former colleagues tell me that he had a huge work ethic and was ever present. Ultimately, however, I think that he was glad to stop.

At 55 he took a special dispensation designed to attract psychiatrists to retire, working as a locum until 60, happily free of the on-call out-calls I remember from my childhood and of the bureaucracy and management.

The average planned and actual retirement age for NHS consultants is now $62 .{ }^{1}$ Changes to pension and salary structures can make it financially advantageous for current senior consultants to retire early, but these changes may keep their successors working longer.

Beyond 50, many doctors start to imagine retirement. It takes longer to recover from busy evenings and weekends on call. Workload expands as leadership roles accumulate. Burnout, poor mental health, addiction, and "compassion fatigue" are increasingly prevalent. ${ }^{2}$ The General Medical Council (GMC) has found that registered UK practitioners over 50 are most likely to be subject to formal complaints. ${ }^{3}$

Physical health problems are more likely with age, and in some jobs they're doubtless caused by the workload or compromise the ability to cope with it. Family life and relationships can suffer as a result.

Because doctors are individuals and different specialties and roles come with different stress levels or performance, ${ }^{12}$ many doctors work into their 60s still healthy, enjoying work, and reluctant to stop. Others seek ongoing involvement in health services, academia, or clinical leadership even after retirement.

Teams and services lose all of that hard won wisdom and experience

The GMC recently highlighted the effect of low morale and burnout on the medical workforce. ${ }^{3}$ The retention crisis in general practice is well described. ${ }^{4}$ But a recent survey of 800 doctors by the Hospital Consultants and Specialists Association showed the problems I've outlined and more, finding high stress levels and most respondents considering an early exit. ${ }^{5}$ Teams and services lose all of that hard won wisdom and experience.

Acute specialties, which require more doctors' presence at evenings, weekends, or overnight, face massive increases in activity and complexity in patient care and are already struggling the hardest to fill training posts. ${ }^{16}$ Discerning applicants have choices: work-life balance is increasingly important to younger generations. $^{7}$

If we can change job roles and requirements to support older doctors, retain the skills they bring, and phase in retirement rather than have them fall off a sharp work-retirement cliff, surely we should?

I'm asking readers how. Please send rapid responses or tweet with the hashtag \#olderdoctors. I'd love to hear from you.

Competing interests: See www.bmj.com/about-bmj/freelancecontributors/david-oliver.

Provenance and peer review: Commissioned; not externally peer reviewed.

1 Royal College of Physicians of London, Royal College of Physicians of Edinburgh, Royal College of Physicians and Surgeons of Glasgow. Census of consultants and higher speciality trainees in the UK 2014-15. https://www.rcplondon.ac.uk/projects/outputs/201415-census-uk-consultants-and-higher-specialty-trainees.

2 Shanafelt TD, Hasan O, Dyrbye LN, et al. Changes in burnout and satisfaction with work-life balance in physicians and the general us working population between 2011 and 2014. Mayo Clin Proc 2015;90:1600-13. www.mayoclinicproceedings.org/article/S00256196(15)00716-8/abstract.

3 General Medical Council. The state of medical education and practice in the UK report: 2016. www.gmc-uk.org/publications/somep2016.asp.

4 Baird B, Charles A, Honeyman M, Maguire D, Das P. Understanding pressures in general practice. King's Fund. 5 May 2016. https://www.kingsfund.org.uk/publications/pressuresin-general-practice.

5 Hospital Consultants and Specialists Association. Who cares for the carers? The impact of workplace stress on senior hospital doctors. Sep 2015.https://www.hcsa.com/newsviews/news/2015/09/stress-survey-initial.aspx.

6 Royal College of Physicians of London. Underdoctored, underfunded, overstretched: the NHS in 2016. Sep 2016. https://www.rcplondon.ac.uk/guidelines-policy/underfundedunderdoctored-overstretched-nhs-2016.

7 Leibow C. Work/life balance for the generations. Huffington Post 2014 Dec 10. www. huffingtonpost.com/cathy-leibow/worklife-balance-for-the-_1_b_5992766.html.

Published by the BMJ Publishing Group Limited. For permission to use (where not already granted under a licence) please go to http://group.bmj.com/group/rights-licensing/ permissions 